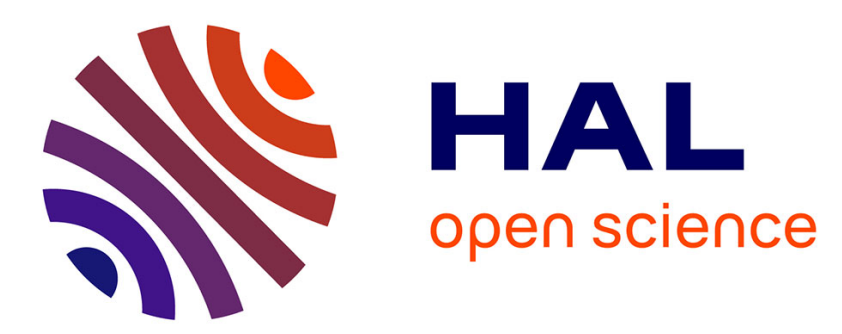

\title{
The yin and the yang of follicular lymphoma cell niches: Role of microenvironment heterogeneity and plasticity.
}

\author{
Patricia Amé-Thomas, Karin Tarte
}

\section{To cite this version:}

Patricia Amé-Thomas, Karin Tarte. The yin and the yang of follicular lymphoma cell niches: Role of microenvironment heterogeneity and plasticity.. Seminars in Cancer Biology, 2014, 24, pp.23-32. 10.1016/j.semcancer.2013.08.001 . inserm-00866220

\section{HAL Id: inserm-00866220 https://www.hal.inserm.fr/inserm-00866220}

Submitted on 13 Jan 2015

HAL is a multi-disciplinary open access archive for the deposit and dissemination of scientific research documents, whether they are published or not. The documents may come from teaching and research institutions in France or abroad, or from public or private research centers.
L'archive ouverte pluridisciplinaire HAL, est destinée au dépôt et à la diffusion de documents scientifiques de niveau recherche, publiés ou non, émanant des établissements d'enseignement et de recherche français ou étrangers, des laboratoires publics ou privés. 
The yin and the yang of follicular lymphoma cell niches: role of microenvironment heterogeneity and plasticity

Patricia Amé-Thomas ${ }^{1,2,3,4}$ and Karin Tarte ${ }^{1,2,3,4}$

1 INSERM, UMR U917, Equipe Labellisée Ligue Contre le Cancer, Rennes, France

${ }^{2}$ Université Rennes 1, Rennes, France

${ }^{3} \mathrm{CHU}$ de Rennes, Service ITeCH, Pôle de Biologie, Rennes, France

${ }^{4}$ EFS Bretagne, Rennes, France

Correspondence Karin TARTE

INSERM UMRU917

Faculté de médecine

2 avenue du Pr Léon Bernard

35043 RENNES, FRANCE

Tel: +33(0)2 23234512

Fax: +33 (0)2 23234958

karin.tarte@univ-rennes1.fr 


\begin{abstract}
Follicular lymphoma $(F L)$ results from the malignant transformation of germinal center $B$ cells and is characterized by recurrent genetic alterations providing a direct growth advantage or facilitating interaction with tumor microenvironment. In agreement, accumulating evidences suggest a dynamic bidirectional crosstalk between FL $B$ cells and surrounding non-malignant cells within specialized tumor niches in both invaded lymph nodes and bone marrow. Infiltrating stromal cells, macrophages, and T/NK cell subsets either contribute to anti-tumor immune response, or conversely form a tumor supportive network promoting FL B cell survival, growth, and drug resistance. This review depicts the phenotypic heterogeneity and functional plasticity of the most important FL cell partners and describes their complex interplay. We also unravel how malignant $B$ cells recruit and subvert accessory immune and stromal cells to trigger their polarization towards a supportive phenotype. Based on these observations, innovative therapeutic approaches have been recently proposed, in order to benefit from local anti-tumor immunity and/or to selectively target the protective cell niche.
\end{abstract}

KEYWORDS: Cell interactions, Stromal cells, follicular helper T cells, macrophages 


\section{Introduction}

Follicular lymphoma (FL) is the most frequent indolent lymphoma and is considered virtually incurable with high response rates to therapy but frequent relapses [1]. Progression to aggressive diffuse large B-cell lymphoma (DLBCL) occurs in about $35 \%$ of cases, an event associated with poor outcome [2]. Malignant FL B cells express germinal center (GC) B-cell markers such as BCL6 and CD10, have somatically mutated immunoglobulin variable genes with ongoing intraclonal diversification, and display a gene expression profile of centrocytes, indicating that $\mathrm{FL}$ results from the malignant transformation of GC-derived B cells [3]. The genetic hallmark of $F L$ is the $t(14 ; 18)$ translocation associated with an overexpression of the anti-apoptotic protein BCL2, actively repressed in normal GC B cells. However, this founder genetic event is detected at a low frequency in most healthy individuals within peripheral blood IgM memory B cells, the so-called FL-like cells (FLLC) [4], suggesting that additional driver genetic events are required to complete cell transformation. Accordingly, genome-wide profiling has recently shed new lights on the mutational landscape in FL and delineated a hierarchical model of successive genetic events supporting FL tumorigenesis [1, 5].

Besides the failure of primary FL cells to survive and grow autonomously in vitro, the major role of the microenvironment in FL development and evolution has been highlighted by several seminal observations. First, like their normal counterpart, malignant FL B cells are found admixed with lymphoid stromal cells, macrophages, and follicular helper $\mathrm{CD} 4^{\text {pos }} \mathrm{T}$ cells $\left(\mathrm{T}_{\mathrm{FH}}\right)$ in $\mathrm{GC}$-like follicles within invaded lymph nodes (LN) [6]. In addition, bone marrow (BM) infiltration found in up to $70 \%$ of patients at diagnosis is characterized by an ectopic differentiation of lymphoid-like stromal cells [7] and local enrichment in $C D 4^{\text {pos }} T$ cells [8] suggesting a critical dependence of malignant $B$ cells to this specific supportive cell niche. Despite these similarities, some differences in cell composition and organization exist between LN and BM niches [8, 9]. In agreement, different subclones could be detected within BM and $\mathrm{LN}$, and BM FL cells are characterized by a lower cytological grade and proliferation [9-11]. These data support the hypothesis that trafficking in various specific microenvironments could contribute to FL clonal selection and molecular heterogeneity [12]. Second, several highly frequent genetic alterations are not oncogenic per se but favor the crosstalk of FL cells with neighboring cells. Among them, mutations in TNFRSF14/HVEM affecting its expression or binding to the 
inhibitory receptor BTLA could contribute to the maintenance and supportive activity of BTLA ${ }^{\text {hi }}$ FL-infiltrating $T_{F H}[13,14]$. Moreover, more than $90 \%$ of FL cases display unusual sites for $\mathrm{N}$-linked glycosylation within their immunoglobulin variable regions introduced during the somatic hypermutation process (SHM) [15]. Added glycans contain oligomannoses that might interact with $\mathrm{C}$-type lectins expressed by myeloid cells in the microenvironment, allowing FL cells to receive antigen-independent but cell contact-dependent survival signals through their BCR [16]. Finally, several studies based on expression profiling and immunohistochemistry have proposed a panel of prognostic biomarkers reflecting the number, activation, and/or spatial organization of infiltrating immune cells, further emphasizing the central role of FL microenvironment [17]. In the landmark study performed on whole tumor biopsies, the clinical outcome of FL patients was primarily predicted by molecular features of non-malignant cells and not by specific genetic characteristics of tumor B cells [18]. However, these studies led to highly contradictory results, in part due to treatment heterogeneity, and remained essentially descriptive without transposition of the data into more functional and mechanistic approaches.

Our current knowledge of the relationship between $\mathrm{FL} B$ cells and their microenvironment has been hindered by four main technical pitfalls: i) the lack of true FL B-cell lines; ii) the lack of relevant transgenic mouse model of FL; iii) the difficulty to establish FL xenografts in immunocompromised mice in the absence of T-cell help and mature secondary lymphoid organs; iv) the heterogeneity and plasticity of the numerous cell subsets involved in FL cell growth, associated to their limited survival and proliferation in vitro. Nevertheless, several recent studies have provided interesting clues illustrating the two faces of FL microenvironment; i.e. its capacity to exert anti-tumor activity by itself or by potentiating the efficacy of FL-targeting drugs versus its capacity to favor directly and indirectly FL B-cell growth. This review will try to integrate them in a comprehensive view of the intricate $\mathrm{FL}$ cell niche. A related interesting question is how malignant $B$ cells co-opt and divert their microenvironment to create a conducive niche in $L N$ and $B M$ and how this niche is modified after treatment and support FL relapse. A better understanding of the ambivalent role of FL microenvironment would be useful to select the more relevant biomarkers for patient stratification and prognosis. It will also make it possible to design new microenvironment-targeted treatments, a field that recently gained increasing attention in B-cell lymphomas. 


\section{Microenvironment can inhibit FL cell growth}

FL has long been considered as particularly immune responsive based on reports of spontaneous regressions, high response rates to monoclonal antibodies (mAb) associated with a long-lasting vaccinal effect, and good biological responses to vaccination using tumor-specific idiotype or immunogenic neoplastic cells [19-22]. Several immune cell subsets could contribute to this anti-tumor activity and provide useful biomarkers and potential therapeutic targets.

\subsection{Cytotoxic lymphoid cells}

$\mathrm{CD} 8^{\text {pos }} \mathrm{T}$ cells are major actors of anti-tumor immunity and an increased $\mathrm{CD} 8^{\mathrm{pos}} \mathrm{T}-$ cell infiltrate is correlated to a better FL prognosis [23]. Similarly, high levels of blood $\mathrm{CD} 3^{\text {pos }}, \mathrm{CD}^{\text {pos }}{ }^{\text {, and }} \mathrm{CD} 8^{\text {pos }}$ predict favorable outcome in patients treated with rituximab [24]. Using 3-D tissue imaging, Laurent et al. described a rich infiltrate of functional $C D 8^{\text {pos }}$ cells containing granzyme $B^{\text {pos }}$ lytic granules in the interfollicular spaces [25]. T cells at the follicular border form lytic synapse-like structures with FL B cells, suggesting a tonic control of malignant cell trafficking and $\mathrm{FL}$ progression. However, a global $C D 8^{\text {pos }} T$-cell exhaustion as well as dysfunctional synapses with FL B cells have been reported in biopsy specimens [26, 27]. In addition, intratumoral regulatory $T$ cells (Treg) have been shown to inhibit in vitro degranulation and cytotoxic activity of infiltrating $\mathrm{CD} 8^{\text {pos }} \mathrm{T}$ cells exposed to lymphoma $\mathrm{B}$ cells [28].

Beside antigen-driven cytotoxicity of $\mathrm{CD} 8^{\text {pos }} \mathrm{T}$ cells, innate anti-tumor cytotoxicity involved essentially NK cells and $\gamma \delta T$ lymphocytes (Figure 1). Our knowledge of in situ NK cells in FL is limited, and the low frequency of CD56 $6^{\text {pos }}$ cells on malignant tissue sections has not been associated with the progression of the disease [29]. However, we could hypothesize an induction of NK-DC crosstalk by therapeutic mAb, which could trigger tumor antigen-specific $T$ cell immunity [30]. Considering $\gamma \delta T$ cells, $\quad \vee \gamma 9 \delta 2 T$ cells recognize tumor phosphoantigens, like isopentenyl pyrophosphate (IPP), and are able to kill in vitro a wide variety of tumor cell lines, as well as primary FL B cells [31]. Whereas $\gamma \delta T$ cells could migrate into GC within normal secondary lymphoid organs [32], immunohistochemistry studies revealed that these cells display mainly perifollicular localization and are represented at lower density in FL LN tissues, compared to reactive LN [33]. Moreover, those FL B cells retaining HVEM expression could inhibit proliferation of $B T L A^{\text {pos }}$ infiltrating $V \gamma 9 \delta 2 T$ 
cells [34]. In agreement, we found a lower in vitro expansion capacity of FL infiltrating $\mathrm{V} \gamma 9 \delta 2 \mathrm{~T}$ cells in response to a combination of their pharmacological agonist bromohydrin pyrophosphate (BrHPP) with IL-2 (our unpublished data). FL B cells were shown to express ULBP proteins, the ligands for NKG2D activating receptor and an increase in circulating ULBP-responsive V $\delta 1 \mathrm{~T}$ lymphocytes have been described in FL patients [35]. However, the role of $V \delta 2^{\text {neg }} \gamma \delta \mathrm{T}$ cells in FL pathogenesis remains poorly understood.

Finally, NK cells, $\gamma \delta$ T lymphocytes, and a subset of $C D 8^{\text {pos }} \mathrm{T}$ cells share the capacity to mediate antibody-dependent cellular cytotoxicity (ADCC), an important mechanism of anti-tumor immune response. The association between Rituximab clinical efficiency and a specific polymorphism in CD16/FcyRllla resulting in a modulation of affinity for IgG1 revealed the critical role of CD16-expressing cells in the activity of this anti-CD20 mAb [36].

Overall, cytotoxic cells of both innate and adaptative immunity could efficiently kill lymphoma B cells but this antitumor immune response is actively counteracted by tumor escape mechanisms affecting immune cell recruitment and activation.

\subsection{Myeloid cells}

Tumor-associated macrophages (TAM) exhibit a dual role in FL pathogenesis, as underlined by the opposite predictive value of a high TAM content, depending on treatment schedule. In fact, high numbers of $\mathrm{CD} 8^{\text {pos }}$ or $\mathrm{CD} 163^{\text {pos }} \mathrm{TAM}$ are associated with adverse outcome in $\mathrm{FL}$ patients treated with conventional chemotherapy, whereas this prognosis value is abrogated or even inversed when Rituximab is combined with chemotherapy [37-39]. These data suggest that FL TAM could favor tumor progression but also contribute to the clinical efficacy of antibodybased anti-lymphoma drugs (Figure 2). Accordingly, B cell depletion with anti-CD20 $m A b$ in mouse models prominently depends on macrophages, and more specifically on their expression of activating Fc $\gamma R$ [40]. In addition, for rituximab-mediated tumor clearance in human, antibody-dependent cellular phagocytosis (ADCP) mediated by macrophages probably plays a key role beside that of NK-mediated ADCC [41]. In particular, Rituximab and Ofatumumab show high direct ADCP capacities in vitro and elicit TNF- $\alpha$ release by macrophages, which could indirectly contribute to NK cell activation [42]. Interestingly, alternatively activated M2 macrophages were shown to 
display in vitro a greater phagocytic capacity towards Rituximab-opsonized B cells from chronic lymphocytic leukemia (CLL), when compared to M1 proinflammatory macrophages [43]. This was associated with a differential regulation of $F c \gamma R$ expression by polarizing cytokines. In agreement, several reports demonstrate that IL-4 decreases expression of CD64/FcyRla whereas IL-10 up-regulates all classes of Fc $\gamma R$ and favors CD32a/FcyRlla-mediated phagocytosis [44]. FL TAM display a $\mathrm{CD} 16^{\text {neg }} \mathrm{CD} 32 \mathrm{a}^{\text {hi }} \mathrm{CD} 64^{\text {hi }}$ phenotype and $\mathrm{CD} 32 \mathrm{a}$ is primarily involved in the phagocytosis of anti-CD20-opsonized primary FL B cells in vitro (our unpublished data). Altogether, the overexpression of both IL-4 and IL-10 within FL microenvironment [45] could modulate the TAM phenotype, including expression levels of $\mathrm{Fc} \gamma \mathrm{Rs}$ and phagocytic properties in the presence of therapeutic antibodies. The clinical relevance of $A D C P$ has been further underlined by the demonstration that $\mathrm{FL}$ and DLBCL $\mathrm{B}$ cells overexpress CD47, a transmembrane protein that enables evasion of phagocytosis through binding to the inhibitory receptor signal regulatory protein (SIRP)- $\alpha$ on macrophages [46]. Accordingly, a blocking mAb targeting CD47 restores phagocytic activity of macrophages in vitro and synergizes with Rituximab for the elimination of human lymphoma in xenotransplant models in NOD-scid II $2 \mathrm{rg}^{\text {null }}$ (NSG) mice. It was recently demonstrated that the genetic determinant favoring human cell engraftment in NOD-based immunodeficient mouse models is a Sirpa gene polymorphism allowing recognition of human CD47 by mouse phagocytes and inhibiting human grafted cell engulfment [47]. This observation could have potential impact for the development of new xenograft models of FL.

Altogether, TAM appear as a highly plastic cell subset involved in antitumor immunity, in particular through FcyR-related ADCP, a process actively inhibited by CD47-expressing malignant $B$ cells.

\subsection{Relevance for the design of new therapies}

The demonstration that several immune cell subsets could efficiently trigger FL B-cell death is difficult to reconcile with the general lack of clinical response following classical antigen-specific immunotherapy strategies. In particular, despite promising proof-of-principle studies, the results of phase III randomized trials examining the clinical impact of idiotypic vaccination in FL were disappointing [21]. Since idiotypes have been shown to be immunogenic, these negative results are likely due to 
mechanisms of avoiding immune cell recruitment, recognition, and lysis by malignant $B$ cells. A better understanding of the relationships between $B$ cells and their immune microenvironment will be highly useful to design new treatments that could overcome immune escape and enhance clinical efficacy of chemotherapy and antibodymediated immunotherapy (Figure 3).

Such approaches are currently explored with immunomodulators like lenalidomide that is evaluated in clinical trials in FL, in combination with Rituximab. Lenalidomide has pleiotropic activities including a substantial capacity to activate NK cells, to increase T-cell proliferation and function, and to enhance macrophage-mediated ADCP of Rituximab-coated tumor cells [48]. The main molecular target of lenalidomide is the E3 ubiquitin ligase cereblon that was recently shown to trigger the induction of cytokine production by $T$ cells [49]. Interestingly, FL infiltrating CD4 ${ }^{\text {pos }}$ and $C D 8^{\text {pos }} \mathrm{T}$ cells display immunological synapse dysfunction with impaired F-actin polymerization [27]. This defect could be reversed after in vitro treatment of both FL and autologous $\mathrm{T}$ cells with lenalidomide. A recent report pinpoints lenalidomide capacity to rescue LFA-1-dependent T-cell adhesion and motility in CLL patients by restoring Rho GTPase activity [50]. The relevance of this mechanism for the clinical activity of lenalidomide in FL remains to be evaluated.

Another important research field is the engineering of modified antibodies with optimized effector properties [51]. GA101 afucosylated anti-CD20 mAb is currently under clinical evaluation in FL and is supposed to mediate greater NK-cell ADCC through a higher affinity for CD16/FcR $\gamma$ IIIA that abrogates the negative impact of the unfavorable FcR $\gamma$ IIIA polymorphism [42]. However, GA101 recently demonstrated inferior ADCP compared with rituximab suggesting that new Fc modifications are required to improve specific binding to CD32a and enhance phagocytosis [52]. Besides targeting directly tumor cells, a new generation of antibodies has been designed to stimulate immune cells in the microenvironment (reviewed in [53]). Among them, agonistic antibodies targeting the inducible co-stimulatory molecule CD137 could favor ADCC and T-cell activation and enhance the antilymphoma activity of anti-CD20 mAb [54]. Similarly, antibodies blocking KIR, the NK inhibitory receptor family, could be useful despite their systemic activation of resting NK cells [55]. Finally, promising immunological and clinical results have been obtained using combination of rituximab, BrHPP, and IL-2 in relapsed FL patients, suggesting that $\gamma \delta$ 
T cells could be activated in vivo and trigger direct cytotoxic activity as well as ADCC owing to their inducible CD16 expression [56]. Targeting immune cells to increase their effector functions should thus be considered as a promising therapeutic strategy in $\mathrm{FL}$, in particular with the aim of optimizing mAb-driven cytotoxicity.

\section{Microenvironment can favor FL cell growth}

Besides its potential role in tumor eradication, FL microenvironment revealed individual tumor supportive activity of each cell subset, including stromal cells, $T_{\mathrm{FH}}$, or TAM, on malignant B-cell recruitment, survival, proliferation, and drug resistance. In addition, the FL cell niche should be envisioned as a dynamic network of cell interactions where the various cell compartments also contribute to migration, expansion, activation, and polarization of each other.

\subsection{Stromal cells}

Cancer-associated fibroblasts (CAF) are phenotypically and functionally different from their normal counterpart and play a key role in tumor development and progression in various cancer models [57]. In FL, LN and BM CAF essentially display some features of lymphoid stromal cells, a heterogeneous cell compartment organized as three specialized cell niches within normal secondary lymphoid organs [58, 59]: i) the mesenchymal stromal network of the T-cell zone is formed by fibroblastic reticular cells (FRC), which provide a foothold for antigen delivery, immune cell recruitment, motility, interaction, and homeostasis through the release of extracellular matrix components, IL-7, VEGF, nitric oxyde, and homeostatic chemokines CCL19, CCL21 and CXCL12; ii) follicular dendritic cells (FDC) drive CXCL13-dependent attraction of $B$ cells and $T_{F H}$ within the $G C$ where they promote the selection of high affinity $B$ cells through the retention and presentation of antigens as immune complexes; iii) finally, marginal reticular cells (MRC) deliver small antigens to cognate $B$ cells though specific follicular conduits. The main common feature of lymphoid stromal cells is to derive from resident local precursors and to require both tumor necrosis factor (TNF)- $\alpha$ and lymphotoxin (LT)- $\alpha 1 \beta 2$ for their maturation and maintenance as immunologically competent cells. In addition, human LN contain bona fide mesenchymal stromal cells (MSC) that can be triggered to adipocyte, osteoblast, and chondrocyte lineages but also to FRC differentiation in response to a combination of TNF- $\alpha$ and LT- $\alpha 1 \beta 2$ [60]. However, the exact origin of 
human lymphoid stromal cells remains elusive in both normal and FL-invaded LN and BM. Moreover, FL LN stromal cells displayed altered in situ phenotype compared to normal LN, including a uniform and marked activation of transglutaminase expressing FRC-like network whereas follicle stromal cells progressively loose classical FDC markers [61-63]. The mechanisms and consequences of these phenotypic modifications are unknown, in particular because functional analysis of native stromal cells remains a highly challenging issue.

MSC obtained after culture of invaded FL BM (FL-MSC) support more efficiently the growth of malignant B cells than MSC obtained from healthy donor BM (HD-MSC) [64]. To better understand this result, we compared the gene expression profile of FL-MSC and HD-MSC and revealed that FL-MSC in the BM are ectopically committed to a FRC-like differentiation. In agreement, FRC-like cells obtained from HD-MSC in response to TNF- $\alpha$ and LT- $\alpha 1 \beta 2$ priming are more powerful to drive malignant B-cell survival than HD-MSC themselves [60]. The tumor-promoting capacity of FL-MSC remains to be molecularly understood (Figure 4).

Stromal cells have been involved in the recruitment of malignant FL B cells through the release of CXCL12 and CXCL13 [60, 65]. They also contribute directly and indirectly to B-cell survival and drug resistance. Accordingly, interaction of malignant $B$ cells and FDC was recently suggested to upregulate MDR1, an ABC transporter triggering multidrug resistance in FL B cells compared to DLBCL [66]. Among the paracrine supportive factors produced by stromal cells, Hedgehog (Hh) ligands, B cell-activating factor of the TNF family (BAFF), IL-15, hepatocyte growth factor (HGF), and the adhesion molecule CD106 have all been proposed to contribute to the antiapoptotic effect of stromal cells on normal and malignant GC B cells [67-74]. Paracrine Hh signaling might also favor stroma-mediated chemotolerance in indolent lymphomas by upregulating the drug transporter ATP-binding cassette (ABC)G2 [75], whereas adhesion of VLA-4 ${ }^{\text {pos }} \mathrm{FL} B$ cells to CD106 ${ }^{\text {pos }}$ stromal cells protects them from rituximab-induced apoptosis [76]. The role of FDC-derived Wnt5a, Notch ligands, and PGE2 in GC-derived lymphomas has not been explored to date. In addition, the question of whether stromal cells transfer paracrine information to malignant B cells remains unanswered. BM-MSC from patients with multiple myeloma release exosomes containing specific microRNA and proteins that support the growth and dissemination of malignant plasma cells [77]. It would be important to 
clarify the role of such microvesicles in the crosstalk between stromal cells and $B$ cells in FL.

Finally, beyond the numerous individual factors suspected to trigger stromal protection of neoplastic cells, a recent paper revealed that BM-MSC promote gluthatione synthesis and survival of CLL B cells [78]. Given the central place of oxydative metabolism in cancer development, it is tempting to speculate that such mechanism could also be involved in the supportive activity of stromal cells in FL context.

FL stromal cells are likely organizers of FL cell niche. In particular, FL-MSC overexpressed CCL2 that favors the recruitment of monocytes and triggers their differentiation into proangiogenic and anti-inflammatory TAM-like macrophages [64]. Interestingly, MSC isolated from spontaneous lymphomas in mouse also overexpress CCR2 ligands and recruit more macrophages than BM-MSC [79]. In addition, IFN- $\gamma$ primes human and mice FRC to produce the immunosuppressive enzymes indoleamine-2,3 dioxygenase (IDO) and nitric oxide synthase 2 (iNOS), respectively $[80,81]$. Since IFN- $\gamma$ is upregulated within FL microenvironment [80], such primed FRC could thereafter inhibit T-cell proliferation and contribute to tumor immune escape.

In conclusion, stromal cells play a central role in FL pathogenesis through both a direct tumor B-cell supportive activity and an indirect effect on the orchestration of $\mathrm{FL}$ cell niche.

\subsection{CD $4^{\text {pos }} T$ cells}

Genes related to $C D 4^{\text {pos }} \mathrm{T}$ cells represent a prominent part of the $\mathrm{FL}$ specific prognostic signature at diagnosis emphasizing the pivotal role of this subset (Figure 1). Despite a global profile of exhausted $T$ cells associated with a high proportion of PD1 and/or TIM3 ${ }^{\text {pos }}$ cells $[26,82]$, FL helper $\mathrm{T}$ cells also display a more activated phenotype than reactive LN helper $T$ cells suggesting a more complex phenotype than previously anticipated [83]. In agreement, fully functional PD-1-expressing $T_{F H}$ are enriched within FL LN thus challenging the idea of a classical anergic T-cell-rich tumor niche [45]. $\mathrm{T}_{\mathrm{FH}}$ were initially identified as CD4 ${ }^{\text {pos }} \mathrm{T}$ cells expressing CXCR5, allowing their localization in follicular areas of secondary lymphoid organs. Recent data broadened the definition of this compartment, and defined it as a distinct helper T-cell lineage, under the control of BCL6, and playing a central role in GC B-cell 
localization, selection, and differentiation in normal follicles [84]. Nevertheless, beside this unique functional definition, the $T_{F H}$ compartment is more heterogeneous than previously assumed, and could be subdivided into several subsets, based on the secretion of various cytokines formerly assigned to other helper $\mathrm{T}$ cell lineages, i.e. IFN- $\gamma$, IL-4, or IL-17 shared with Th1, Th2, and Th17 cells; respectively. FL-TFH display a specific gene expression profile compared to tonsil- $T_{F H}$, with an overexpression of IL4, IL2, IFNG, and TNF [85]. High levels of IL-4, essentially produced by $\mathrm{T}_{\mathrm{FH}}$, have been associated with a STAT6 and Erk-dependent FL B-cell activation $[45,86]$ and recent evidences highlighted a potential role of $\mathrm{T}_{\mathrm{FH}}$-derived CD40L in malignant B-cell survival [85, 87]. Beside this direct protumoral activity, FL$\mathrm{T}_{\mathrm{FH}}$ could also modulate the $\mathrm{FL}$ supportive niche through their expression of TNF and LTA that sustain differentiation and maintenance of the B-cell supportive lymphoid stroma network [60]. In addition, $\mathrm{FL}-\mathrm{T}_{\mathrm{FH}}$ secrete high amounts of IFN- $\gamma$, thus inducing the expression by stromal cells of the tryptophan-catabolizing enzyme IDO [80] and could contribute by their overexpression of IL-4 to the polarization of TAM within the malignant cell niche [88].

Analyzes of dissociated FL biopsies revealed also a higher frequency of Treg compared with non-malignant $L N$ or tonsils $[85,89]$. Treg have been experimentally described to inhibit the anti-tumor immune responses in FL by suppressing the proliferation and activity of intratumoral $C D 4^{\text {pos }}$ and $C D 8^{\text {pos }} T$ cells $[28,89]$. Elevated levels of soluble IL-2R $\alpha$ have been involved in the inhibitory activity of FL-Treg and predict reduced survival in FL [90]. More importantly, an excessive number of Foxp $3^{\text {pos }} \mathrm{CXCR}^{\text {hi }}$ follicular Treg $\left(\mathrm{T}_{\mathrm{FR}}\right)$ has been specifically reported in FL neoplastic follicles. Strikingly, the follicular localization of Foxp $3^{\text {pos }} \mathrm{T}$ cells rather than their absolute number was recently associated with a worse overall survival, suggesting that $T_{F R}$ are the more relevant Treg subset for FL biology [91]. These cells share phenotypic characteristics with $\mathrm{T}_{\mathrm{FH}}$, and express a higher level of BCL6, the master regulator of $\mathrm{T}_{\mathrm{FH}}$ differentiation pathway, than classical Treg [85]. $\mathrm{T}_{\mathrm{FR}}$ also strongly express the co-stimulatory molecule ICOS, as reported for a subset of Treg with strong suppressive functions and able to induce IL-4-secreting $T$ cells [92]. Suppressive $T_{F R}$ have also been described in mice. They control the GC reaction by limiting $T_{F H}$ number and inhibiting the selection of non-cognate $B$ cells [93]. Nevertheless, the targets of the specific FL- $T_{F R}$ subset are currently unknown. It is 
tempting to speculate that $\mathrm{FL}-\mathrm{T}_{\mathrm{FR}}$ inhibit anti-tumor responses, thus explaining the worse prognosis associated with their expansion. However, we could not exclude that $\mathrm{FL}-\mathrm{T}_{\mathrm{FR}}$ also contribute to a limitation of the $\mathrm{FL}-\mathrm{T}_{\mathrm{FH}}$ compartment, in agreement with a lower proportion of $\mathrm{KI} 67^{\mathrm{pos}} \mathrm{FL}-\mathrm{T}_{\mathrm{FH}}$, compared to tonsil- $\mathrm{T}_{\mathrm{FH}}$ (our unpublished data). If this hypothesis is confirmed, the high proportion of FL- $T_{F H}$ should result from a preferential commitment of activated $\mathrm{CD} 4^{\text {pos }} \mathrm{T}$ cells into $\mathrm{T}_{\mathrm{FH}}$ differentiation pathway, or an increased survival of differentiated $\mathrm{T}_{\mathrm{FH}}$ in response to tumor-specific surrounding growth factors, rather than a proliferation of a mature $T_{F H}$ compartment. Altogether, these results highlight the role of various $\mathrm{CD} 4^{\text {pos }} \mathrm{T}$-cell subsets in $\mathrm{FL} \mathrm{B}$ cell growth as well as immune escape. In particular, $\mathrm{T}_{\mathrm{FH}}$ and Treg are strongly modulated both quantitatively and qualitatively during FL pathogenesis.

\subsection{Myeloid cells}

Although several studies have proposed TAM number as a prognostic marker, knowledge of their direct role in B-cell growth and how they cooperate with neighboring infiltrating T cells and stromal cells is still rudimentary (Figure 2). BAFF is a well-known myeloid-derived B-cell growth factor. Even if BAFF expression is not increased in FL patients [94], a polymorphism in TNFSF13B/BAFF was associated with an increased risk of developing $\mathrm{FL}$, whereas a germline mutation in TNFRSF13C/BAFF-R was specifically detected in $10 \%$ of $F L$ patients in association with a stronger BAFF-induced signaling $[95,96]$. Another potential TAM-mediated pathway in FL is BCR signaling. In fact, whereas a recent study suggests that $B C R$ from a subset of $F L$ patients recognize self-antigens potentially retained on the surface of FDC [97], the majority of FL B cells express mannosylated BCR able to interact with C-type lectins DC-SIGN (CD209) and Mannose Receptor (CD206) independently of antigens [15, 16]. CD209 and CD206 are known to be upregulated on M2 macrophages and on TAM in solid tumors [98], a situation mirrored in FL by the overexpression of IL-4 by $\mathrm{T}_{\mathrm{FH}}$ [45]. FL- $\mathrm{T}_{\mathrm{FH}}$ also overexpress CD40L that both increases IL-15R $\alpha$ expression on myeloid cells [99] and confers IL-15 sensitivity to B cells through induction of STAT5 expression and activation [70]. In agreement, FLTAM overexpress $I L 15$ compared to tonsil macrophages and FL $B$ cells overexpress STAT5A compared to normal GC B cells. Interestingly, IFN- $\gamma$, which is also upregulated in FL microenvironment [80], was shown to increase the migration of macrophages in response to CCL2 through an upregulation of STAT1 expression 
[100]. Such activation loop should be important for the recruitment of macrophages by $\mathrm{CCL} 2^{\text {hi }} \mathrm{FL}$ stromal cells and the presence of STAT $1^{\text {pos }} \mathrm{CD} 68^{\text {pos }}$ macrophages in the vicinity of FL B cells was associated with unfavorable outcome [101]. Finally FLTAM could contribute to local immune escape through the release of immunosuppressive molecules like IL4I1 [102] but also to angiogenesis. Accordingly, increased angiogenic sprouting correlates both with elevated numbers of CD163 $3^{\text {pos }}$ macrophages and poor prognosis [103]. In parallel to the description of in situ TAM, circulating CD14 ${ }^{\text {pos }}$ HLA-DR ${ }^{10}$ suppressive monocytes have been identified in B-cell $\mathrm{NHL}$ [104] and the absolute monocyte count is inversely correlated with overall survival in FL and DLBCL [105]. Overall, myeloid compartment display specific features in $\mathrm{FL}$ and contribute to $\mathrm{FL}$ pathogenesis through the release of tumor growth factors, proangiogenic molecules, and immunosuppressive mediators.

\subsection{Relevance for the design of new therapies}

Since interaction of FL B cells with their microenvironment is postulated to be an important mediator of drug resistance and disease relapse, targeting B-cell adhesion and/or retention within tumor niches has recently emerged as a promising therapeutic approach (Figure 3). Anti-VLA-4 mAb natalizumab has been shown to overcome stroma-mediated resistance to Rituximab [76]. In addition, disrupting the CXCL12/CXCR4 axis using the CXCR4 antagonist perixafor (AMD3100) or cellpenetrating peptides targeting CXCR4 may augment the effects of anti-CD20 mAb $[106,107]$. Interestingly, the Btk inhibitor PCI-32765, the PI3K inhibitor GS-1101, and Syk inhibitors do not only target BCR signaling but also impair chemokine networks and reduce CLL cell retention in protective microenvironment [108-110]. The combination of these two properties could be highly useful in FL. Lenalidomide also decreases CXCL12 production by stromal cells and alters CLL migration by targeting Rho protein activity $[111,112]$. Finally, the tyrosine kinase inhibitor imatinib was demonstrated to impair xenografted lymphoma B-cell growth through a direct targeting of vascular mural cells resulting in loss of tumor vascular integrity [113]. This innovative finding paves the way for the introduction of antiangiogenic agents in our therapeutic arsenal in FL.

Besides stromal cells, $\mathrm{CD} 4^{\text {pos }} \mathrm{T}$-cell help is crucial for $\mathrm{FL}$ survival and growth and represents an interesting druggable target. Antagonist mAb to PD-1 and PD-L1 showed both a good safety profile and antitumor activity in some metastatic cancers [114]. They are supposed to block inhibitory PD-1 signaling on tumor infiltrating $T$ 
cells or to deplete PD-1 ${ }^{\text {pos }}$ anergic T cells depending on antibody isotype. In FL, PD-1 is not only expressed on anergic $T$ cells but also on fully functional $T_{F H}$ and $T_{F R}$, and PD-L1/PD-1 pathway has been recently demonstrated to inhibit proliferation and function of both cell types [115, 116]. The use of anti-PD-1 mAb in this specific context should thus be highly valuable but would also benefit from extensive patient monitoring to unravel the exact target of these drugs. Of course, the recent development of other immune-checkpoint inhibitors, such as anti-CTLA4 mAb should also be considered for patients with $\mathrm{FL}$.

Beyond stimulation of effector immune cells, inhibition of protumoral $T$ and stromal cells through kinase inhibitors or antagonistic mAb emerges as a valuable therapeutic approach in FL.

\section{Malignant $B$ cells can subvert their microenvironment}

It is now well-established that tumor cells could subvert their molecular and cellular environment to favor their own growth, and to minimize anti-tumor immune response. Accordingly, the recruitment and polarization of the various microenvironment cell subsets in $\mathrm{FL}$ is at least partly governed by the malignant clone (Figures 1 \& 4).

Indeed, FL B cells directly contribute to the differentiation and maintenance of the dense FRC meshwork within invaded LN [60]. This FRC commitment is partly dependent on TNF- $\alpha$ secretion by malignant B cells, as exemplified for the induction of CCL2 in HD-MSC after contact with primary FL B cells. Invasion of BM by malignant GC B cells expressing TNF- $\alpha$ and LT- $\alpha 1 \beta 2$ likely induces ectopic lymphoid-like stromal cells.

Malignant $B$ cells also modify their chemokine environment through a direct secretion of CCL22 that recruits Treg. In addition, they contribute to the polarization of helper T cells. In particular, GC-derived lymphomas skew the balance of Th17 versus Treg differentiation in favor of an increased frequency of induced Treg, and both CD27CD70 and CD28-CD80/CD86 axes are involved in this process $[117,118]$. Moreover, induction of TIM-3 on anergic T cells relies on malignant B-cell-derived IL-12 [26] whereas expression of multiple inhibitory ligands on $B$ cells has been proposed to trigger T-cell synapse defect [119]. Despite data suggesting a thymic origin of mice $T_{F R}$ in physiological conditions [93], we could not exclude that the specific FL- $T_{F R}$ subset emerges at least in part from a tumor-driven in situ conversion of $\mathrm{T}_{\mathrm{FH}}$ into induced Treg. In support of this hypothesis, a strong correlation exists between FL- 
$T_{F H}$ and $F L-T_{F R}$ contents [85]. Whereas the mechanisms of $F L-T_{F H}$ expansion remain unknown, they should arise from a preferential GC-recruitment and/or commitment of activated helper $T$ cells into $T_{F H}$. FL B cells could be involved in this process through their overexpression of IL-6 and ICOS ligand (ICOS-L), compared to tonsil GC B cells (our unpublished data). First, it is now well documented that IL-6, in association with IL-21, promotes BCL6 expression in activated CD4 ${ }^{\text {pos }} T$ cells [120]. Second, ICOS-L expression by follicular bystander $\mathrm{B}$ cells has been recently demonstrated to control the recruitment of activated $\mathrm{CD} 4^{\text {pos }} \mathrm{T}$ cells into $\mathrm{GC}$ allowing their further differentiation into $T_{F H}$ independently of cognate T-B or T-DC interaction [121]. In the context of FL, such co-stimulation independent function of ICOS is presumably important, as suggested by the fully polyclonal repertoire of infiltrating $F L-T_{F H}$ (our unpublished data). Thus, FL B cells are able to trigger recruitment, polarization, and maintenance of $\mathrm{CD} 4^{\text {pos }} \mathrm{T}$ cells that in turn promote their survival and growth.

\section{Concluding remarks}

Genetic and functional studies corroborate the general concept that immune and stromal microenvironment plays a proactive role in the development and progression of $\mathrm{FL}$ and determines clinical behavior and response to treatment. The major goal of numerous recent studies was to unravel the different facets of FL cell niche and to define how they interact with each other. However several burning questions remain unsolved. Longitudinal follow-up of microenvironment composition will be helpful to define the kinetic of $\mathrm{B}$ cell/microenvironment bidirectional interactions. When do the first modifications of $\mathrm{LN}$ and BM niches occur and more specifically could some of them be detected at the FLLC pre-malignant stage? Comparison of microenvironment composition at diagnosis, in the context of residual disease, and in relapse would be instrumental to identify the minimal cell niche protecting malignant $B$ cells from drug-induced cytotoxicity and to better understand the impact of treatments on the various microenvironment cell subsets. The role of the microenvironment in the selection of malignant B-cell subclones should be further analyzed. In particular, what are the molecular features of BM versus LN FL cells depending on their specific cell niche? Altogether, developing new tools to better understand microenvironment network may provide innovative tailored strategies to disrupt supportive niches whereas taking advantage of anti-lymphoma infiltrating cells. 


\section{Acknowledgements}

Karin Tarte is supported by research grants from the Institut National du Cancer, the Ligue Contre le Cancer (Equipe Labellisée 2013), and the Fondation ARC pour la Recherche sur le Cancer.

\section{Conflict of interest statement}

The authors declare that there are no conflicts of interest. 


\section{References}

[1] Kridel R, Sehn LH, Gascoyne RD. Pathogenesis of follicular lymphoma. J Clin Invest. 2012;122:3424-31.

[2] Montoto S, Davies AJ, Matthews J, Calaminici M, Norton AJ, Amess J, et al. Risk and clinical implications of transformation of follicular lymphoma to diffuse large Bcell lymphoma. J Clin Oncol. 2007;25:2426-33.

[3] Shaffer AL, 3rd, Young RM, Staudt LM. Pathogenesis of human B cell lymphomas. Annu Rev Immunol. 2012;30:565-610.

[4] Roulland S, Faroudi M, Mamessier E, Sungalee S, Salles G, Nadel B. Early steps of follicular lymphoma pathogenesis. Advances in immunology. 2011;111:1-46.

[5] Green MR, Gentles AJ, Nair RV, Irish JM, Kihira S, Liu CL, et al. Hierarchy in somatic mutations arising during genomic evolution and progression of follicular lymphoma. Blood. 2013;121:1604-11.

[6] Carbone A, Gloghini A, Cabras A, Elia G. The Germinal centre-derived lymphomas seen through their cellular microenvironment. $\mathrm{Br} J$ Haematol. 2009;145:468-80.

[7] Vega F, Medeiros LJ, Lang WH, Mansoor A, Bueso-Ramos C, Jones D. The stromal composition of malignant lymphoid aggregates in bone marrow: variations in architecture and phenotype in different B-cell tumours. Br J Haematol. 2002;117:56976.

[8] Wahlin BE, Sander B, Christensson B, Ostenstad B, Holte H, Brown PD, et al. Entourage: the immune microenvironment following follicular lymphoma. Blood Cancer Journal. 2012;2:e52.

[9] Rajnai H, Bodor C, Balogh Z, Gagyi E, Csomor J, Krenacs T, et al. Impact of the reactive microenvironment on the bone marrow involvement of follicular lymphoma. Histopathology. 2012;60:E66-75.

[10] Bognar A, Csernus B, Bodor C, Reiniger L, Szepesi A, Toth E, et al. Clonal selection in the bone marrow involvement of follicular lymphoma. Leukemia. 2005;19:1656-62.

[11] Ruminy P, Jardin F, Picquenot JM, Parmentier F, Contentin N, Buchonnet G, et al. $\mathrm{S}(\mathrm{mu})$ mutation patterns suggest different progression pathways in follicular lymphoma: early direct or late from FL progenitor cells. Blood. 2008;112:1951-9.

[12] Wartenberg M, Vasil P, Meyer Zum Bueschenfelde C, Ott G, Rosenwald A, Fend $F$, et al. Somatic hypermutation analysis in follicular lymphoma provides evidence suggesting bidirectional cell migration between lymph node and bone marrow during disease progression and relapse. Haematologica. 2013.

[13] Launay E, Pangault C, Bertrand P, Jardin F, Lamy T, Tilly $H$, et al. High rate of TNFRSF14 gene alterations related to 1 p36 region in de novo follicular lymphoma and impact on prognosis. Leukemia. 2012;26:559-62.

[14] Pasero C, Speiser DE, Derre L, Olive D. The HVEM network: new directions in targeting novel costimulatory/co-inhibitory molecules for cancer therapy. Current opinion in pharmacology. 2012;12:478-85.

[15] Stevenson FK, Stevenson GT. Follicular lymphoma and the immune system: from pathogenesis to antibody therapy. Blood. 2012;119:3659-67.

[16] Coelho V, Krysov S, Ghaemmaghami AM, Emara M, Potter KN, Johnson P, et al. Glycosylation of surface Ig creates a functional bridge between human follicular lymphoma and microenvironmental lectins. Proc Natl Acad Sci U S A. 2010;107:18587-92. 
[17] Relander T, Johnson NA, Farinha P, Connors JM, Sehn LH, Gascoyne RD. Prognostic factors in follicular lymphoma. J Clin Oncol. 2010;28:2902-13.

[18] Dave SS, Wright G, Tan B, Rosenwald A, Gascoyne RD, Chan WC, et al. Prediction of survival in follicular lymphoma based on molecular features of tumorinfiltrating immune cells. N Engl J Med. 2004;351:2159-69.

[19] Di Nicola M, Zappasodi R, Carlo-Stella C, Mortarini R, Pupa SM, Magni M, et al. Vaccination with autologous tumor-loaded dendritic cells induces clinical and immunologic responses in indolent B-cell lymphoma patients with relapsed and measurable disease: a pilot study. Blood. 2009;113:18-27.

[20] Hilchey SP, Hyrien O, Mosmann TR, Livingstone AM, Friedberg JW, Young F, et al. Rituximab immunotherapy results in the induction of a lymphoma idiotype-specific T-cell response in patients with follicular lymphoma: support for a "vaccinal effect" of rituximab. Blood. 2009;113:3809-12.

[21] Bendandi M. Idiotype vaccines for lymphoma: proof-of-principles and clinical trial failures. Nat Rev Cancer. 2009;9:675-81.

[22] Horning SJ, Rosenberg SA. The natural history of initially untreated low-grade non-Hodgkin's lymphomas. N Engl J Med. 1984;311:1471-5.

[23] Alvaro T, Lejeune M, Salvado MT, Lopez C, Jaen J, Bosch R, et al. Immunohistochemical patterns of reactive microenvironment are associated with clinicobiologic behavior in follicular lymphoma patients. J Clin Oncol. 2006;24:5350-7. [24] Wahlin BE, Sundstrom C, Holte H, Hagberg H, Erlanson M, Nilsson-Ehle H, et al. T cells in tumors and blood predict outcome in follicular lymphoma treated with rituximab. Clin Cancer Res. 2011;17:4136-44.

[25] Laurent C, Muller S, Do C, Al-Saati T, Allart S, Larocca LM, et al. Distribution, function, and prognostic value of cytotoxic $T$ lymphocytes in follicular lymphoma: a 3D tissue-imaging study. Blood. 2011;118:5371-9.

[26] Yang ZZ, Grote DM, Ziesmer SC, Niki T, Hirashima M, Novak AJ, et al. IL-12 upregulates TIM-3 expression and induces $\mathrm{T}$ cell exhaustion in patients with follicular B cell non-Hodgkin lymphoma. J Clin Invest. 2012;122:1271-82.

[27] Ramsay AG, Clear AJ, Kelly G, Fatah R, Matthews J, Macdougall F, et al. Follicular lymphoma cells induce T-cell immunologic synapse dysfunction that can be repaired with lenalidomide: implications for the tumor microenvironment and immunotherapy. Blood. 2009;114:4713-20.

[28] Yang ZZ, Novak AJ, Ziesmer SC, Witzig TE, Ansell SM. Attenuation of CD8(+) T-cell function by CD4(+)CD25(+) regulatory $\mathrm{T}$ cells in B-cell non-Hodgkin's lymphoma. Cancer Res. 2006;66:10145-52.

[29] Glas AM, Knoops L, Delahaye L, Kersten MJ, Kibbelaar RE, Wessels LA, et al. Gene-expression and immunohistochemical study of specific T-cell subsets and accessory cell types in the transformation and prognosis of follicular lymphoma. $\mathrm{J}$ Clin Oncol. 2007;25:390-8.

[30] Lee SC, Srivastava RM, Lopez-Albaitero A, Ferrone S, Ferris RL. Natural killer (NK): dendritic cell (DC) cross talk induced by therapeutic monoclonal antibody triggers tumor antigen-specific T cell immunity. Immunologic research. 2011;50:24854.

[31] Braza MS, Klein B, Fiol G, Rossi JF. gammadelta T-cell killing of primary follicular lymphoma cells is dramatically potentiated by GA101, a type II glycoengineered anti-CD20 monoclonal antibody. Haematologica. 2011;96:400-7.

[32] Brandes M, Willimann K, Lang AB, Nam KH, Jin C, Brenner MB, et al. Flexible migration program regulates gamma delta T-cell involvement in humoral immunity. Blood. 2003;102:3693-701. 
[33] Braza MS, Caraux A, Rousset T, Lafaye de Micheaux S, Sicard H, Squiban P, et al. gammadelta $\mathrm{T}$ lymphocytes count is normal and expandable in peripheral blood of patients with follicular lymphoma, whereas it is decreased in tumor lymph nodes compared with inflammatory lymph nodes. J Immunol. 2010;184:134-40.

[34] Gertner-Dardenne J, Fauriat C, Orlanducci F, Thibult ML, Pastor S, Fitzgibbon J, et al. The co-receptor BTLA negatively regulates human Vgamma9Vdelta2 $\mathrm{T}$ cell proliferation: a potential way of immune escape for lymphoma cells. Blood. 2013.

[35] Catellani S, Poggi A, Bruzzone A, Dadati P, Ravetti JL, Gobbi M, et al. Expansion of Vdelta1 $\mathrm{T}$ lymphocytes producing IL-4 in low-grade non-Hodgkin lymphomas expressing UL-16-binding proteins. Blood. 2007;109:2078-85.

[36] Cartron G, Dacheux L, Salles G, Solal-Celigny P, Bardos P, Colombat P, et al. Therapeutic activity of humanized anti-CD20 monoclonal antibody and polymorphism in IgG Fc receptor FcgammaRIIla gene. Blood. 2002;99:754-8.

[37] Farinha P, Masoudi H, Skinnider BF, Shumansky K, Spinelli JJ, Gill K, et al. Analysis of multiple biomarkers shows that lymphoma-associated macrophage (LAM) content is an independent predictor of survival in follicular lymphoma (FL). Blood. 2005;106:2169-74.

[38] Canioni D, Salles G, Mounier N, Brousse N, Keuppens M, Morchhauser F, et al. High numbers of tumor-associated macrophages have an adverse prognostic value that can be circumvented by rituximab in patients with follicular lymphoma enrolled onto the GELA-GOELAMS FL-2000 trial. J Clin Oncol. 2008;26:440-6.

[39] Taskinen M, Karjalainen-Lindsberg ML, Nyman H, Eerola LM, Leppa S. A high tumor-associated macrophage content predicts favorable outcome in follicular lymphoma patients treated with rituximab and cyclophosphamide-doxorubicinvincristine-prednisone. Clin Cancer Res. 2007;13:5784-9.

[40] Minard-Colin V, Xiu Y, Poe JC, Horikawa M, Magro CM, Hamaguchi Y, et al. Lymphoma depletion during CD20 immunotherapy in mice is mediated by macrophage FcgammaRI, FcgammaRIII, and FcgammaRIV. Blood. 2008;112:120513.

[41] Manches O, Lui G, Chaperot L, Gressin R, Molens JP, Jacob MC, et al. In vitro mechanisms of action of rituximab on primary non-Hodgkin lymphomas. Blood. 2003;101:949-54.

[42] Rafiq S, Butchar JP, Cheney C, Mo X, Trotta R, Caligiuri M, et al. Comparative assessment of clinically utilized CD20-directed antibodies in chronic lymphocytic leukemia cells reveals divergent NK cell, monocyte, and macrophage properties. J Immunol. 2013;190:2702-11.

[43] Leidi M, Gotti E, Bologna L, Miranda E, Rimoldi M, Sica A, et al. M2 macrophages phagocytose rituximab-opsonized leukemic targets more efficiently than $\mathrm{m} 1$ cells in vitro. J Immunol. 2009;182:4415-22.

[44] Liu Y, Masuda E, Blank MC, Kirou KA, Gao X, Park MS, et al. Cytokinemediated regulation of activating and inhibitory Fc gamma receptors in human monocytes. J Leukoc Biol. 2005;77:767-76.

[45] Pangault C, Ame-Thomas P, Ruminy P, Rossille D, Caron G, Baia M, et al. Follicular lymphoma cell niche: identification of a preeminent IL-4-dependent TFH-B cell axis. Leukemia. 2010;24:2080-9.

[46] Chao MP, Alizadeh AA, Tang C, Myklebust JH, Varghese B, Gill S, et al. AntiCD47 antibody synergizes with rituximab to promote phagocytosis and eradicate non-Hodgkin lymphoma. Cell. 2010;142:699-713. 
[47] Yamauchi T, Takenaka K, Urata S, Shima T, Kikushige Y, Tokuyama T, et al. Polymorphic Sirpa is the genetic determinant for NOD-based mouse lines to achieve efficient human cell engraftment. Blood. 2013;121:1316-25.

[48] Wu L, Adams M, Carter T, Chen R, Muller G, Stirling D, et al. Lenalidomide enhances natural killer cell and monocyte-mediated antibody-dependent cellular cytotoxicity of rituximab-treated CD20+ tumor cells. Clin Cancer Res. 2008;14:46507.

[49] Lopez-Girona A, Mendy D, Ito T, Miller K, Gandhi AK, Kang J, et al. Cereblon is a direct protein target for immunomodulatory and antiproliferative activities of lenalidomide and pomalidomide. Leukemia. 2012;26:2326-35.

[50] Ramsay AG, Evans R, Kiaii S, Svensson L, Hogg N, Gribben JG. Chronic lymphocytic leukemia cells induce defective LFA-1-directed T-cell motility by altering Rho GTPase signaling that is reversible with lenalidomide. Blood. 2013;121:2704-14. [51] Desjarlais JR, Lazar GA. Modulation of antibody effector function. Exp Cell Res. 2011;317:1278-85.

[52] Richards JO, Karki S, Lazar GA, Chen H, Dang W, Desjarlais JR. Optimization of antibody binding to FcgammaRlla enhances macrophage phagocytosis of tumor cells. Mol Cancer Ther. 2008;7:2517-27.

[53] Houot R, Kohrt HE, Marabelle A, Levy R. Targeting immune effector cells to promote antibody-induced cytotoxicity in cancer immunotherapy. Trends Immunol. 2011;32:510-6.

[54] Kohrt HE, Houot R, Goldstein MJ, Weiskopf K, Alizadeh AA, Brody J, et al. CD137 stimulation enhances the antilymphoma activity of anti-CD20 antibodies. Blood. 2011;117:2423-32.

[55] Romagne F, Andre P, Spee P, Zahn S, Anfossi N, Gauthier L, et al. Preclinical characterization of 1-7F9, a novel human anti-KIR receptor therapeutic antibody that augments natural killer-mediated killing of tumor cells. Blood. 2009;114:2667-77.

[56] Braza MS, Klein B. Anti-tumour immunotherapy with Vgamma9Vdelta2 T lymphocytes: from the bench to the bedside. Br J Haematol. 2013;160:123-32.

[57] Hanahan D, Coussens LM. Accessories to the crime: functions of cells recruited to the tumor microenvironment. Cancer Cell. 2012;21:309-22.

[58] Mueller SN, Germain RN. Stromal cell contributions to the homeostasis and functionality of the immune system. Nat Rev Immunol. 2009;9:618-29.

[59] Roozendaal R, Mebius RE. Stromal cell-immune cell interactions. Annu Rev Immunol. 2011;29:23-43.

[60] Amé-Thomas P, Maby-El Hajjami H, Monvoisin C, Jean R, Monnier D, CauletMaugendre $S$, et al. Human mesenchymal stem cells isolated from bone marrow and lymphoid organs support tumor B-cell growth: role of stromal cells in follicular lymphoma pathogenesis. Blood. 2007;109:693-702.

[61] Thomazy VA, Vega F, Medeiros LJ, Davies PJ, Jones D. Phenotypic modulation of the stromal reticular network in normal and neoplastic lymph nodes: tissue transglutaminase reveals coordinate regulation of multiple cell types. Am J Pathol. 2003;163:165-74.

[62] Chang KC, Huang X, Medeiros LJ, Jones D. Germinal centre-like versus undifferentiated stromal immunophenotypes in follicular lymphoma. J Pathol. 2003;201:404-12.

[63] Jin MK, Hoster E, Dreyling M, Unterhalt M, Hiddemann W, Klapper W. Follicular dendritic cells in follicular lymphoma and types of non-Hodgkin lymphoma show reduced expression of CD23, CD35 and CD54 but no association with clinical outcome. Histopathology. 2011;58:586-92. 
[64] Guilloton F, Caron G, Ménard C, Pangault C, Amé-Thomas P, Dulong J, et al. Mesenchymal stromal cells orchestrate follicular lymphoma cell niche through the CCL2-dependent recruitment and polarization of monocytes. Blood. 2012;119:255667.

[65] Husson H, Freedman AS, Cardoso AA, Schultze J, Munoz O, Strola G, et al. CXCL13 (BCA-1) is produced by follicular lymphoma cells: role in the accumulation of malignant B cells. Br J Haematol. 2002;119:492-5.

[66] Yagi K, Yamamoto K, Umeda S, Abe S, Suzuki S, Onishi I, et al. Expression of multidrug resistance 1 gene in B-cell lymphomas: association with follicular dendritic cells. Histopathology. 2013;62:414-20.

[67] Sacedon R, Diez B, Nunez V, Hernandez-Lopez C, Gutierrez-Frias C, Cejalvo T, et al. Sonic hedgehog is produced by follicular dendritic cells and protects germinal center B cells from apoptosis. J Immunol. 2005;174:1456-61.

[68] Dierks C, Grbic J, Zirlik K, Beigi R, Englund NP, Guo GR, et al. Essential role of stromally induced hedgehog signaling in B-cell malignancies. Nat Med. 2007;13:94451.

[69] Park CS, Yoon SO, Armitage RJ, Choi YS. Follicular Dendritic Cells Produce IL15 That Enhances Germinal Center B Cell Proliferation in Membrane-Bound Form. J Immunol. 2004;173:6676-83.

[70] Epron G, Ame-Thomas P, Le Priol J, Pangault C, Dulong J, Lamy T, et al. Monocytes and $T$ cells cooperate to favor normal and follicular lymphoma B-cell growth: role of IL-15 and CD40L signaling. Leukemia. 2012;26:139-48.

[71] Tjin EP, Bende RJ, Derksen PW, van Huijstee AP, Kataoka H, Spaargaren M, et al. Follicular dendritic cells catalyze hepatocyte growth factor (HGF) activation in the germinal center microenvironment by secreting the serine protease HGF activator. J Immunol. 2005;175:2807-13.

[72] Tjin EP, Groen RW, Vogelzang I, Derksen PW, Klok MD, Meijer HP, et al. Functional analysis of HGF/MET signaling and aberrant HGF-activator expression in diffuse large B-cell lymphoma. Blood. 2006;107:760-8.

[73] Mueller CG, Boix C, Kwan WH, Daussy C, Fournier E, Fridman WH, et al. Critical role of monocytes to support normal B cell and diffuse large B cell lymphoma survival and proliferation. J Leukoc Biol. 2007;82:567-75.

[74] Lwin T, Crespo LA, Wu A, Dessureault S, Shu HB, Moscinski LC, et al. Lymphoma cell adhesion-induced expression of B cell-activating factor of the TNF family in bone marrow stromal cells protects non-Hodgkin's B lymphoma cells from apoptosis. Leukemia. 2009;23:170-7.

[75] Singh RR, Kim JE, Davuluri Y, Drakos E, Cho-Vega JH, Amin HM, et al. Hedgehog signaling pathway is activated in diffuse large B-cell lymphoma and contributes to tumor cell survival and proliferation. Leukemia. 2010;24:1025-36.

[76] Mraz M, Zent CS, Church AK, Jelinek DF, Wu X, Pospisilova S, et al. Bone marrow stromal cells protect lymphoma B-cells from rituximab-induced apoptosis and targeting integrin alpha-4-beta-1 (VLA-4) with natalizumab can overcome this resistance. Br J Haematol. 2011;155:53-64.

[77] Roccaro AM, Sacco A, Maiso P, Azab AK, Tai YT, Reagan M, et al. BM mesenchymal stromal cell-derived exosomes facilitate multiple myeloma progression. J Clin Invest. 2013;123:1542-55.

[78] Zhang W, Trachootham D, Liu J, Chen G, Pelicano H, Garcia-Prieto C, et al. Stromal control of cystine metabolism promotes cancer cell survival in chronic lymphocytic leukaemia. Nature cell biology. 2012;14:276-86. 
[79] Ren G, Zhao X, Wang Y, Zhang X, Chen X, Xu C, et al. CCR2-dependent recruitment of macrophages by tumor-educated mesenchymal stromal cells promotes tumor development and is mimicked by TNFalpha. Cell stem cell. 2012;11:812-24.

[80] Maby-El Hajjami H, Ame-Thomas P, Pangault C, Tribut O, DeVos J, Jean R, et al. Functional alteration of the lymphoma stromal cell niche by the cytokine context: role of indoleamine-2,3 dioxygenase. Cancer Res. 2009;69:3228-37.

[81] Lukacs-Kornek V, Malhotra D, Fletcher AL, Acton SE, Elpek KG, Tayalia P, et al. Regulated release of nitric oxide by nonhematopoietic stroma controls expansion of the activated T cell pool in lymph nodes. Nat Immunol. 2011;12:1096-104.

[82] Myklebust JH, Irish JM, Brody J, Czerwinski DK, Houot R, Kohrt HE, et al. High PD-1 expression and suppressed cytokine signaling distinguish $\mathrm{T}$ cells infiltrating follicular lymphoma tumors from peripheral T cells. Blood. 2013;121:1367-76.

[83] Hilchey SP, Rosenberg AF, Hyrien O, Secor-Socha S, Cochran MR, Brady MT, et al. Follicular lymphoma tumor-infiltrating T-helper $(T(H))$ cells have the same polyfunctional potential as normal nodal $\mathrm{T}(\mathrm{H})$ cells despite skewed differentiation. Blood. 2011;118:3591-602.

[84] Fazilleau N, Mark L, McHeyzer-Williams LJ, McHeyzer-Williams MG. Follicular helper T cells: lineage and location. Immunity. 2009;30:324-35.

[85] Amé-Thomas P, Le Priol J, Yssel H, Caron G, Pangault C, Jean R, et al. Characterization of intratumoral follicular helper $T$ cells in follicular lymphoma: role in the survival of malignant B cells. Leukemia. 2012;26:1053-63.

[86] Calvo KR, Dabir B, Kovach A, Devor C, Bandle R, Bond A, et al. IL-4 protein expression and basal activation of Erk in vivo in follicular lymphoma. Blood. 2008;112:3818-26.

[87] Travert M, Ame-Thomas P, Pangault C, Morizot A, Micheau O, Semana G, et al. CD40 ligand protects from TRAIL-induced apoptosis in follicular lymphomas through NF-kappaB activation and up-regulation of c-FLIP and Bcl-xL. J Immunol. 2008;181:1001-11.

[88] Gocheva V, Wang HW, Gadea BB, Shree T, Hunter KE, Garfall AL, et al. IL-4 induces cathepsin protease activity in tumor-associated macrophages to promote cancer growth and invasion. Genes \& development. 2010;24:241-55.

[89] Yang ZZ, Novak AJ, Stenson MJ, Witzig TE, Ansell SM. Intratumoral CD4+CD25+ regulatory T-cell-mediated suppression of infiltrating CD4+ T cells in Bcell non-Hodgkin lymphoma. Blood. 2006;107:3639-46.

[90] Yang ZZ, Grote DM, Ziesmer SC, Manske MK, Witzig TE, Novak AJ, et al. Soluble IL-2Ralpha facilitates IL-2-mediated immune responses and predicts reduced survival in follicular B-cell non-Hodgkin lymphoma. Blood. 2011;118:2809-20.

[91] Farinha P, Al-Tourah A, Gill K, Klasa R, Connors JM, Gascoyne RD. The architectural pattern of FOXP3-positive $T$ cells in follicular lymphoma is an independent predictor of survival and histologic transformation. Blood. 2010;115:28995.

[92] Strauss L, Bergmann C, Szczepanski MJ, Lang S, Kirkwood JM, Whiteside TL. Expression of ICOS on Human Melanoma-Infiltrating CD4+CD25highFoxp3+ T Regulatory Cells: Implications and Impact on Tumor-Mediated Immune Suppression. J Immunol. 2008;180:2967-80.

[93] Linterman MA, Pierson W, Lee SK, Kallies A, Kawamoto S, Rayner TF, et al. Foxp3+ follicular regulatory $T$ cells control the germinal center response. Nat Med. 2011;17:975-82. 
[94] Novak AJ, Grote DM, Stenson M, Ziesmer SC, Witzig TE, Habermann TM, et al. Expression of BLyS and Its Receptors in B-Cell Non-Hodgkin Lymphoma: Correlation With Disease Activity and Patient Outcome. Blood. 2004;104:2247-53.

[95] Novak AJ, Slager SL, Fredericksen ZS, Wang AH, Manske MM, Ziesmer S, et al. Genetic variation in B-cell-activating factor is associated with an increased risk of developing B-cell non-Hodgkin lymphoma. Cancer Res. 2009;69:4217-24.

[96] Hildebrand JM, Luo Z, Manske MK, Price-Troska T, Ziesmer SC, Lin W, et al. A BAFF-R mutation associated with non-Hodgkin lymphoma alters TRAF recruitment and reveals new insights into BAFF-R signaling. J Exp Med. 2010;207:2569-79.

[97] Sachen KL, Strohman MJ, Singletary J, Alizadeh AA, Kattah NH, Lossos C, et al. Self-antigen recognition by follicular lymphoma B-cell receptors. Blood. 2012;120:4182-90.

[98] Dominguez-Soto A, Sierra-Filardi E, Puig-Kroger A, Perez-Maceda B, GomezAguado F, Corcuera MT, et al. Dendritic cell-specific ICAM-3-grabbing nonintegrin expression on M2-polarized and tumor-associated macrophages is macrophage-CSF dependent and enhanced by tumor-derived IL-6 and IL-10. J Immunol. 2011;186:2192-200.

[99] Zhang M, Yao Z, Dubois S, Ju W, Muller JR, Waldmann TA. Interleukin-15 combined with an anti-CD40 antibody provides enhanced therapeutic efficacy for murine models of colon cancer. Proc Natl Acad Sci U S A. 2009;106:7513-8.

[100] Hu X, Park-Min KH, Ho HH, Ivashkiv LB. IFN-gamma-primed macrophages exhibit increased CCR2-dependent migration and altered IFN-gamma responses mediated by Stat1. J Immunol. 2005;175:3637-47.

[101] Alvaro T, Lejeune M, Camacho FI, Salvado MT, Sanchez L, Garcia JF, et al. The presence of STAT1-positive tumor-associated macrophages and their relation to outcome in patients with follicular lymphoma. Haematologica. 2006;91:1605-12.

[102] Carbonnelle-Puscian A, Copie-Bergman C, Baia M, Martin-Garcia N, Allory Y, Haioun $C$, et al. The novel immunosuppressive enzyme IL4I1 is expressed by neoplastic cells of several B-cell lymphomas and by tumor-associated macrophages. Leukemia. 2009;23:952-60.

[103] Clear AJ, Lee AM, Calaminici M, Ramsay AG, Morris KJ, Hallam S, et al. Increased angiogenic sprouting in poor prognosis $\mathrm{FL}$ is associated with elevated numbers of CD163+ macrophages within the immediate sprouting microenvironment. Blood. 2010;115:5053-6.

[104] Lin Y, Gustafson MP, Bulur PA, Gastineau DA, Witzig TE, Dietz AB. Immunosuppressive CD14+HLA-DR(low)/- monocytes in B-cell non-Hodgkin lymphoma. Blood. 2011;117:872-81.

[105] Wilcox RA, Ristow K, Habermann TM, Inwards DJ, Micallef IN, Johnston PB, et al. The absolute monocyte count is associated with overall survival in patients newly diagnosed with follicular lymphoma. Leuk Lymphoma. 2012;53:575-80.

[106] Hu Y, Gale M, Shields J, Garron C, Swistak M, Nguyen TH, et al. Enhancement of the anti-tumor activity of therapeutic monoclonal antibodies by CXCR4 antagonists. Leuk Lymphoma. 2012;53:130-8.

[107] O'Callaghan K, Lee L, Nguyen N, Hsieh MY, Kaneider NC, Klein AK, et al. Targeting CXCR4 with cell-penetrating pepducins in lymphoma and lymphocytic leukemia. Blood. 2012;119:1717-25.

[108] de Rooij MF, Kuil A, Geest CR, Eldering E, Chang BY, Buggy JJ, et al. The clinically active BTK inhibitor PCl-32765 targets B-cell receptor- and chemokinecontrolled adhesion and migration in chronic lymphocytic leukemia. Blood. 2012;119:2590-4. 
[109] Hoellenriegel J, Meadows SA, Sivina M, Wierda WG, Kantarjian H, Keating MJ, et al. The phosphoinositide 3'-kinase delta inhibitor, CAL-101, inhibits B-cell receptor signaling and chemokine networks in chronic lymphocytic leukemia. Blood. 2011;118:3603-12.

[110] Hoellenriegel J, Coffey GP, Sinha U, Pandey A, Sivina M, Ferrajoli A, et al. Selective, novel spleen tyrosine kinase (Syk) inhibitors suppress chronic lymphocytic leukemia B-cell activation and migration. Leukemia. 2012;26:1576-83.

[111] Wobus M, Benath G, Ferrer RA, Wehner R, Schmitz M, Hofbauer LC, et al. Impact of lenalidomide on the functional properties of human mesenchymal stromal cells. Exp Hematol. 2012;40:867-76.

[112] Troeger A, Johnson AJ, Wood J, Blum WG, Andritsos LA, Byrd JC, et al. RhoH is critical for cell-microenvironment interactions in chronic lymphocytic leukemia in mice and humans. Blood. 2012;119:4708-18.

[113] Ruan J, Luo M, Wang C, Fan L, Yang SN, Cardenas M, et al. Imatinib disrupts lymphoma angiogenesis by targeting vascular pericytes. Blood. 2013;121:5192-202.

[114] Sznol M, Chen L. Antagonist antibodies to PD-1 and B7-H1 (PD-L1) in the treatment of advanced human cancer. Clin Cancer Res. 2013;19:1021-34.

[115] Sage PT, Francisco LM, Carman CV, Sharpe AH. The receptor PD-1 controls follicular regulatory T cells in the lymph nodes and blood. Nat Immunol. 2013;14:15261.

[116] Cubas RA, Mudd JC, Savoye AL, Perreau M, van Grevenynghe J, Metcalf T, et al. Inadequate $T$ follicular cell help impairs B cell immunity during HIV infection. Nat Med. 2013;19:494-9.

[117] Yang ZZ, Novak AJ, Ziesmer SC, Witzig TE, Ansell SM. Malignant B cells skew the balance of regulatory T cells and TH17 cells in B-cell non-Hodgkin's lymphoma. Cancer Res. 2009;69:5522-30.

[118] Yang ZZ, Novak AJ, Ziesmer SC, Witzig TE, Ansell SM. CD70+ non-Hodgkin lymphoma $\mathrm{B}$ cells induce Foxp3 expression and regulatory function in intratumoral CD4+CD25 T cells. Blood. 2007;110:2537-44.

[119] Ramsay AG, Clear AJ, Fatah R, Gribben JG. Multiple inhibitory ligands induce impaired T-cell immunologic synapse function in chronic lymphocytic leukemia that can be blocked with lenalidomide: establishing a reversible immune evasion mechanism in human cancer. Blood. 2012;120:1412-21.

[120] Linterman MA, Vinuesa CG. Signals that influence $T$ follicular helper cell differentiation and function. Seminars in immunopathology. 2010;32:183-96.

[121] Xu H, Li X, Liu D, Li J, Zhang X, Chen X, et al. Follicular T-helper cell recruitment governed by bystander $B$ cells and ICOS-driven motility. Nature. 2013;496:523-7. 


\section{Figure Legends}

Figure 1. Dual role of infiltrating T/NK cells in follicular lymphoma cell niche FL- $T_{F H}$ support malignant B-cell growth through $\mathrm{CD} 40 \mathrm{~L}$ and IL-4 signaling. Conversely, cytotoxic CD8 ${ }^{\text {pos }} \mathrm{T}$ cells, $\gamma \delta \mathrm{T}$ cells, and NK cells display anti-tumoral activity and CD16-mediated ADCC is a major mechanism of action of Rituximab mAb. FL B cells subvert antitumor response leading to T-cell immune synapse dysfunction and T-cell exhaustion, to a preferential recruitment of Treg, and to an imbalance in Treg/Th17 polarization in favor of induced Treg. In addition, malignant cells could encourage $T_{F H}$ commitment through their overexpression of ICOS-L and IL-6.

Figure 2. Dual role of infiltrating macrophages in follicular lymphoma cell niche Tumor-associated macrophages (TAM) contribute directly to malignant B-cell growth through BCR, IL-15, and BAFF signaling, and display proangiogenic and immunosuppressive properties. Conversely, FL-TAM participate to the therapeutic efficacy of anti-CD20 mAb through B-cell phagocytosis, a process inhibited by CD47/SIRP $\alpha$ axis, and activation of cognate cytotoxic $T$ cells. FL- $T_{F H}$ cooperate with FL-TAM for promoting STAT5 activation in B cells and produce cytokines, including IL-4, IL-10, and IFN- $\gamma$, involved in TAM migration, polarization, and function.

\section{Figure 3. New drugs to target FL tumor microenvironment}

Lenalidomide exerts pleiotropic activities including activation of NK cells, T cells, and macrophage-mediated antibody dependent phagocytosis. Similarly, inhibitors of Btk and Syk exhibit broader mechanisms of action than initially anticipated and target not only BCR-mediated signal but also B cell/stromal cell interactions. Stromal cell niche could also be disrupted using CXCR4 antagonists and anti-VLA4 mAb. Several therapeutic mAb, including anti-PD-1, anti-CTLA4, anti-CD47, and anti-CD137, target tumor immune cells instead of malignant B cells whereas BrHPP is a specific $\gamma \delta T$-cell agonist. Finally, imatinib was recently shown to compromise tumor-associated microvasculature through a selective inhibitory effect on pericytes. 


\section{Figure 4. Role of infiltrating stromal cells in follicular lymphoma cell niche}

Stromal cells recruit and support directly the growth of FL B cells through a combination of chemokines, adhesion molecules, and cytokines. The role of antigenpresentation by FDC remains speculative. This protumoral property is strongly influenced by the local cytokine context. TNF- $\alpha$ (TNF) and LT- $\alpha 1 \beta 2$ (LT) produced by malignant $B$ cells and $T_{F H}$ trigger stromal cell engagement into lymphoid stroma differentiation whereas IFN- $\gamma$ could favor production of T-cell inhibitory enzyme IDO. Finally, FL stromal cells efficiently recruit TAM through the specific release of CCL2 chemokine. 
Figure 1

\section{Pro-tumoral activity}

Th17

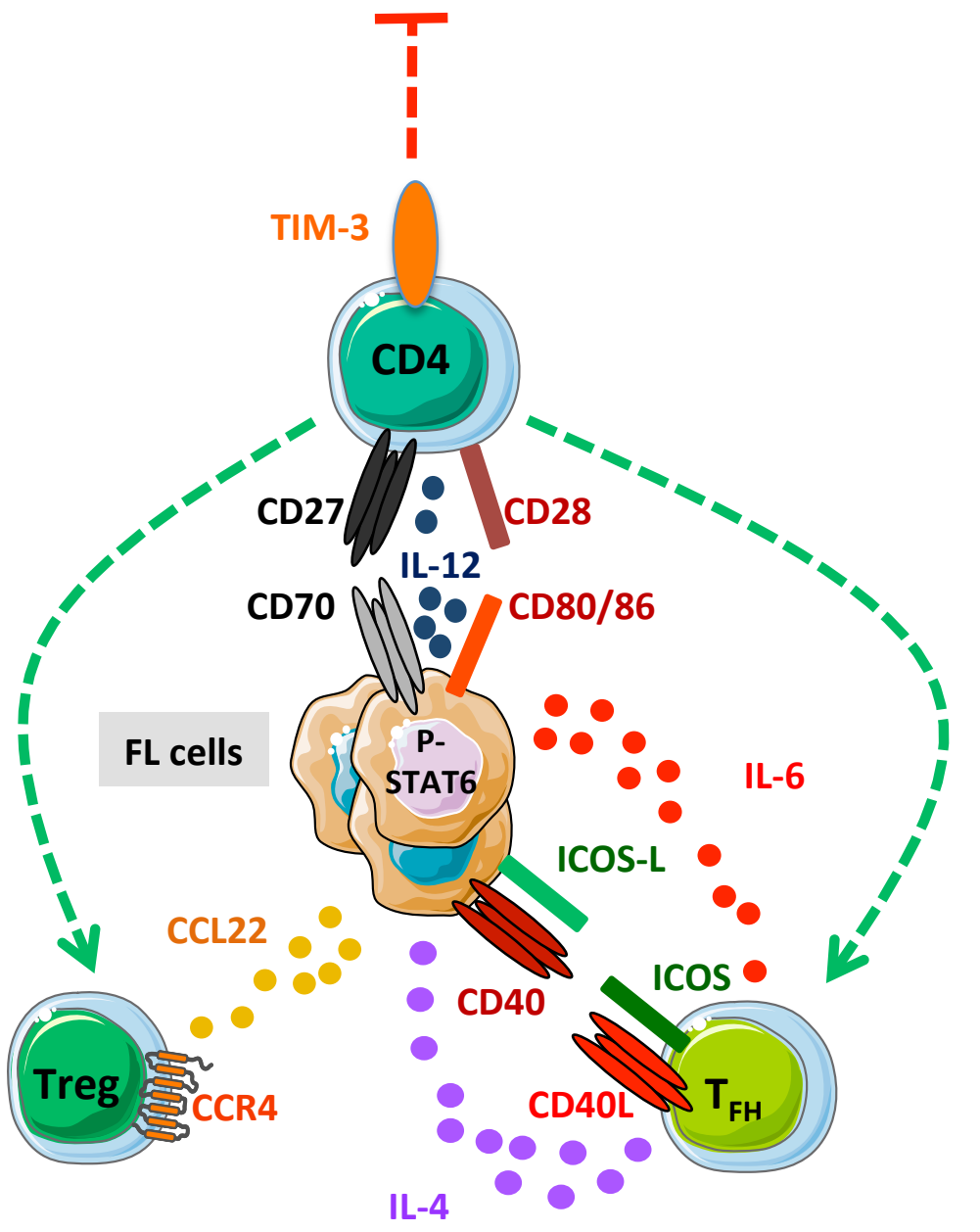

\section{Anti-tumoral activity}

NK

CD16

Rituximab

FL cells

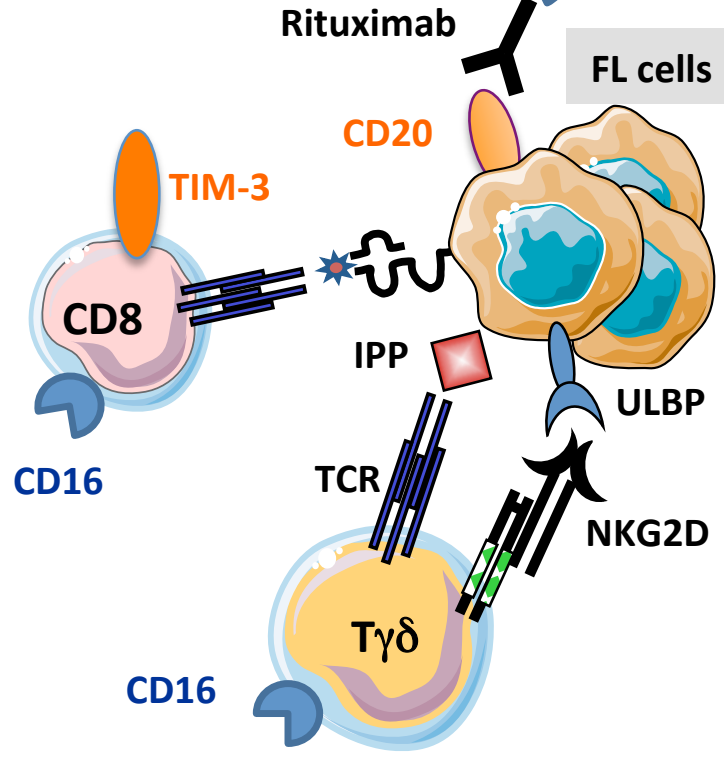

CD16

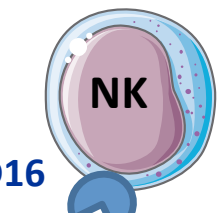


Figure 2

Pro-tumoral activity
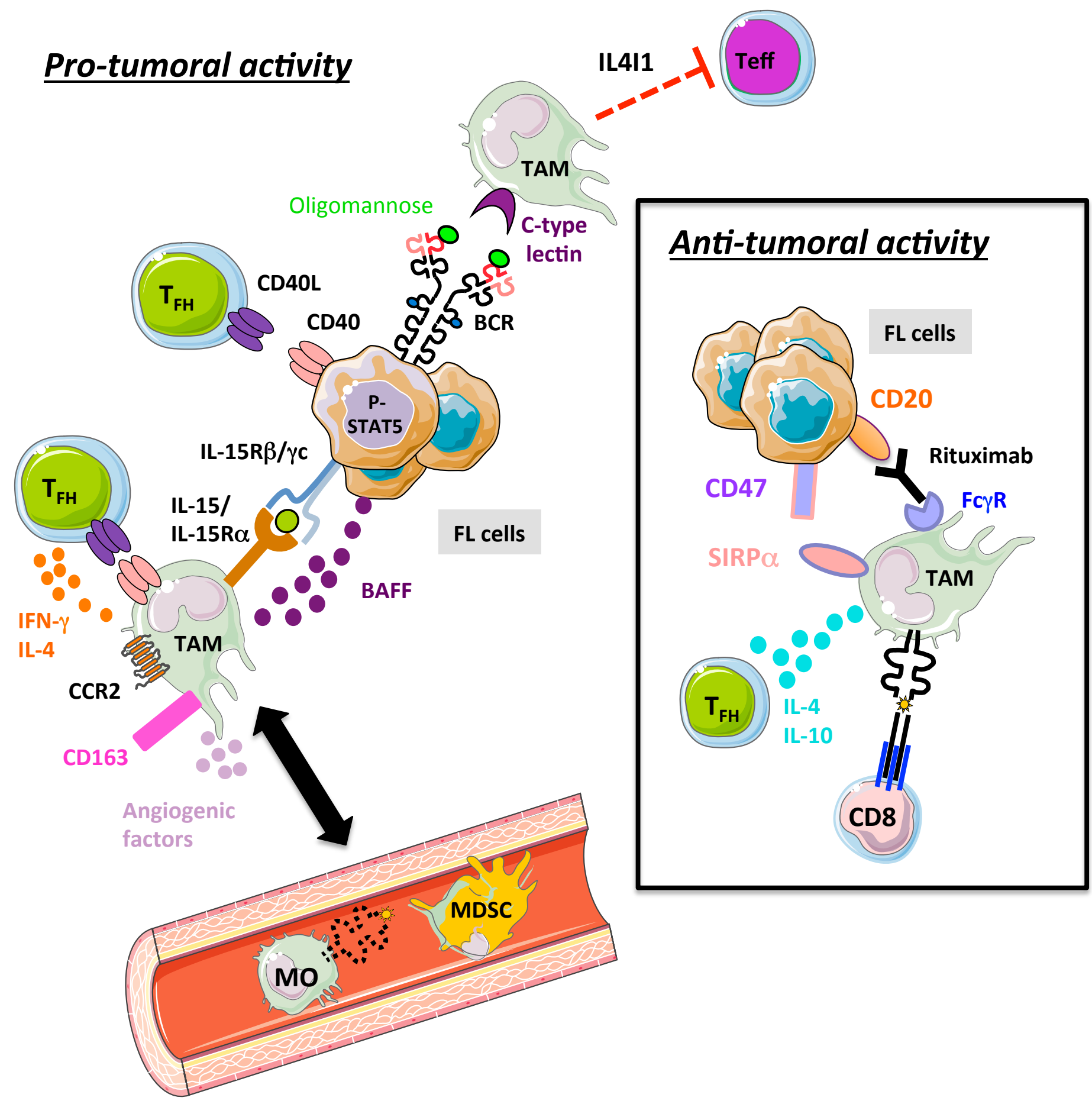


\section{Figure 3}

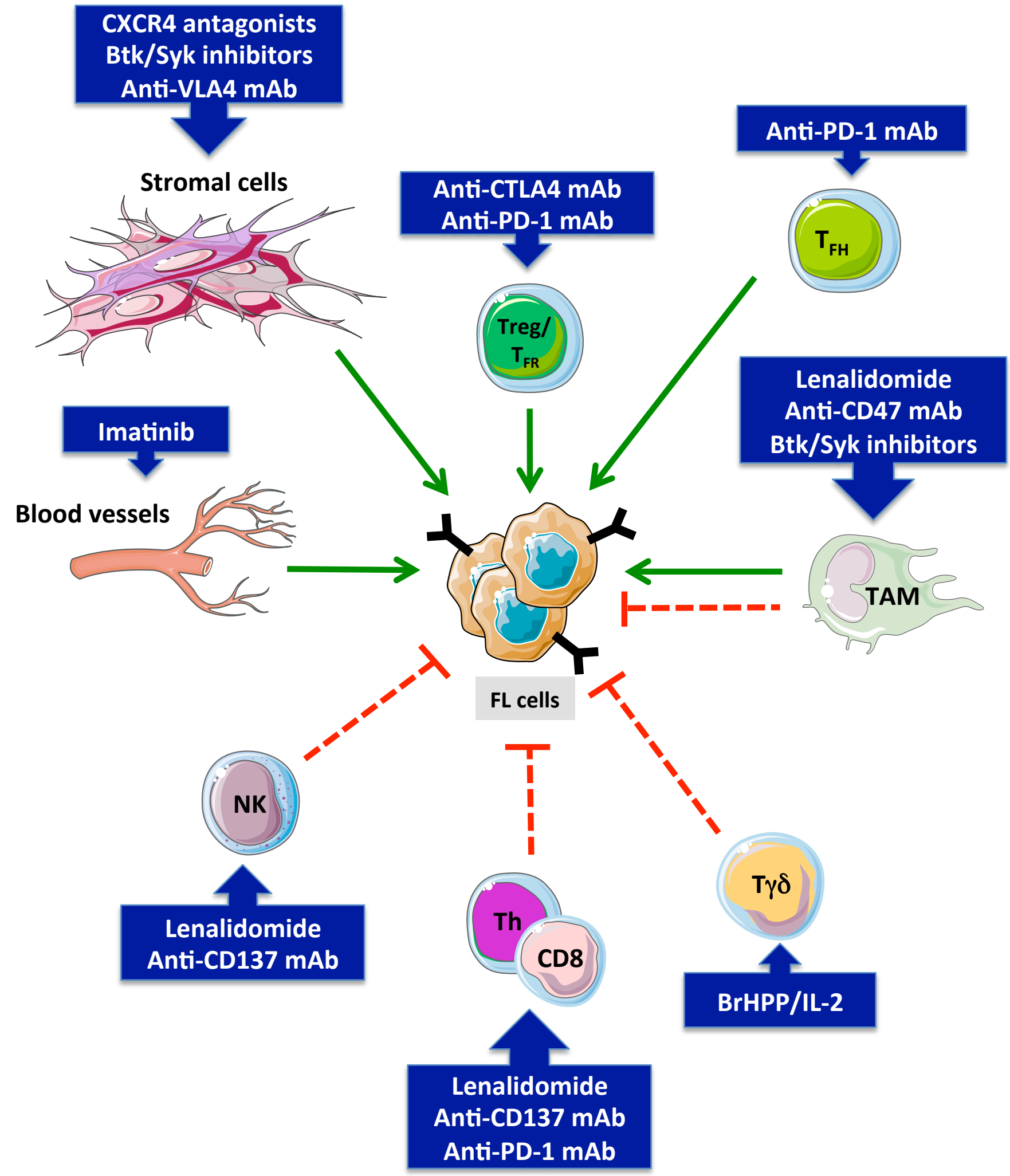


Figure 4

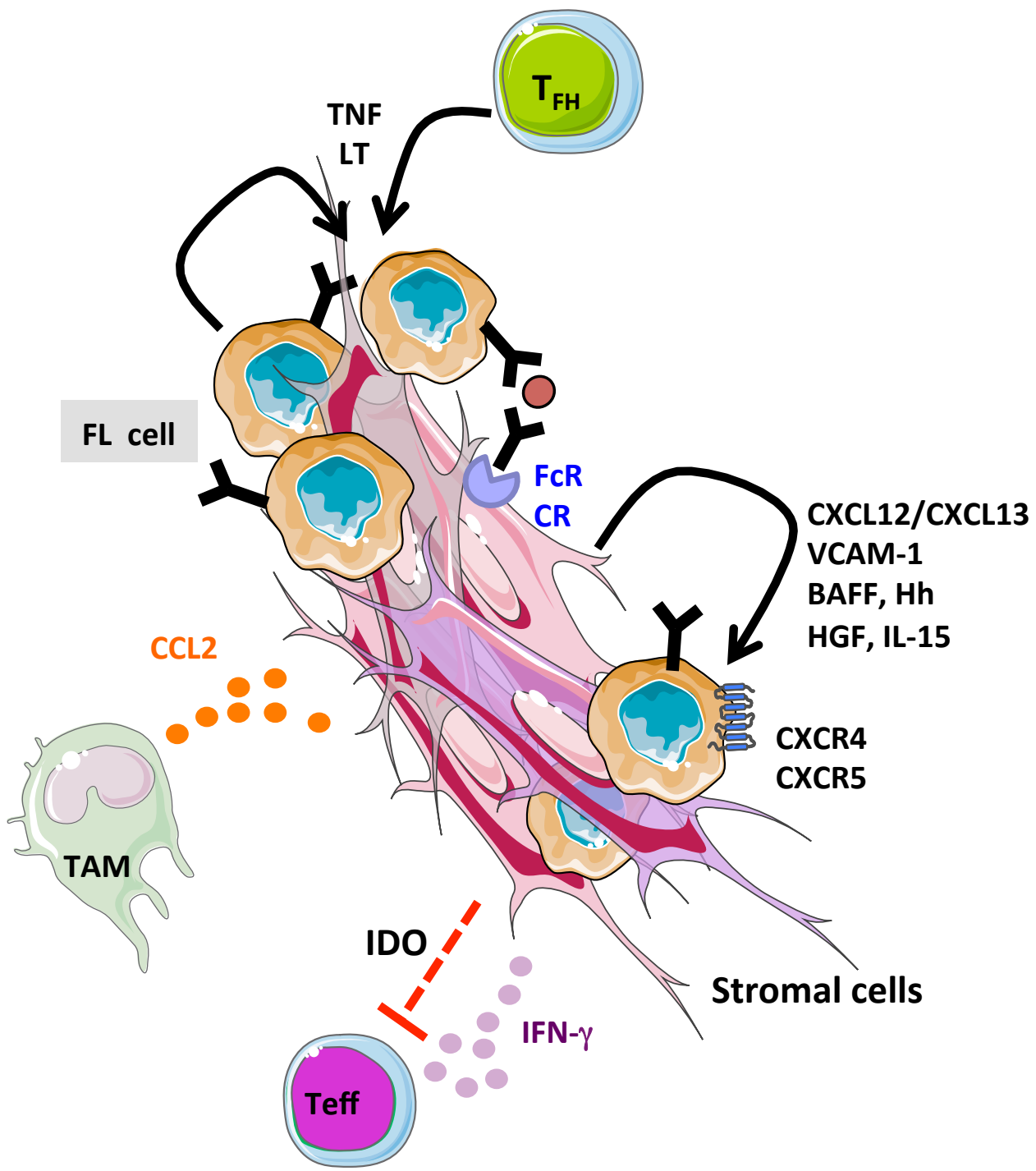

